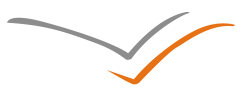

VERSITA

\title{
Geomorphosite assessment for geotourism purposes
}

\author{
Lucie Kubalíková / e-mail: luciekubalikova@seznam.cz \\ Department of geography, Faculty of Education, Technical University in Liberec, Czech Republic
}

Kubalíková, L. (2013). Geomorphosite assessment for geotourism purposes. Czech Journal of Tourism, 2(2), 80-104. DOI: 10.2478/cjot-2013-0005.

\begin{abstract}
The article briefly examines the relationship between geodiversity, geoheritage (represented by geosites and geomorphosites) and geotourism. It is obvious that geosites and geomorphosites represent a fundamental resource for geotourism. As geosites are defined as sites that present particular importance for the comprehension of the Earth history and bear mainly scientific values, geomorphosites concept is wider and includes also added values (e. g. cultural, aesthetic and economic). Therefore, for assessing the importance of the geological and geomorphological sites for geotourism purposes, the concept of geomorphosites is more appropriate. The article presents several assessment methods that represent a significant tool for geoconservation and geotourism purposes. The assessment is carried out from several perspectives with an emphasis on scientific, cultural and economic parameters of the sites. The results of the assessment can serve as a basis for appropriate use of geoheritage, its management and generally for identification of geotourism potential of the geological and geomorphological sites. To find out which method is suitable for geotourism purposes, it is necessary to take into account the definitions and principles of geotourism. Different assessment methods are analysed and discussed. Based on this, the proposal for criteria for geosite and geomorphosite assessment for geotourism purposes is presented.
\end{abstract}

\section{Keywords}

Geodiversity, geotourism, geosites, geomorphosites, assessment methods and criteria

JEL classification: Q100, L83 / Accepted: 12 December 2013 


\section{Introduction}

Geodiversity plays a key role both in environment and human activities. The complex relationships between geology, natural processes, landforms, landscape, soils and climate are fundamental to the distribution of habitats and species. It also provides many essential natural resources that society and economic growth depend on, including the soils, aggregates, metals and fuel (Gray, 2004). The cultural and economic influence of geodiversity on people is also extremely strong; the location of many cities was influenced by the distribution of mineral or soil resources, the location of important fortification systems was also affected by the presence of appropriate landforms. The geologic, geomorphologic and other abiotic features can be also seen as a resource for tourism, respectively geotourism activities which may affect local development (Panizza, 1996; Panizza \& Piacente, 2008).

According to Dowling (2011), the geotourism is defined as a form of nature tourism that specifically focuses on landscape and geology - these components are an important part of geodiversity (Gray, 2004). The geotourism promotes tourism to geosites and the conservation of geodiversity and an understanding of Earth sciences through appreciation and learning (Newsome \& Dowling, 2010). It is obvious that not only geological but also geomorphological features and processes are considered as a resource for geotourism.

Reynard, et al. (2003) analyzed the relationship between geomorphology and tourism: geomorphology may be a tourist resource as part of the primary or original offer (geomorphological site as an attraction or geomorphological site as a support for tourist activity, e. g. climbing) and secondary or derived offer, when tourist infrastructures (e.g. didactic trails), instruments (e.g. educational booklets) or services (e.g. guided tours) are proposed for effective use of the original offer. Gray (2004) also stated that geodiversity, respectively geoheritage, was of great value for geotouristic and geoeducational activities - it is one of the functions of geodiversity.

It is evident that geodiversity as a whole cannot be used for geotourism purposes; tourist use of geodiversity is generally made through the exploitation of geosites and geomorphosites (Pralong \& Reynard, 2005). This is a quite general statement and it does not respond to the question "which sites exactly are suitable for such exploitation?" For the detection of such sites, it is necessary to do the inventory and evaluation of potential sites. The concept of geosites and geomorphosites seems to be suitable for this purpose because it includes plenty of assessment methods for evaluation of geosites and geomorphosites from different points of view.

\section{Theoretical basis: geodiversity, geoconservation, geosites, geomorphosites}

The geodiversity concept first appeared in the early 90's in Australia, respectively Tasmania and it was defined as "the diversity of Earth features and systems" (Sharples, 1993). Later, the definition was extended (Sharples, 1995; Dixon, 1996; Australian Heri- 
tage Commission, 2002; Sharples, 2002) and it included "the range or diversity of geological (bedrock), geomorphological (landform) and soil features, assemblages, systems and processes" (Australian Heritage Commission, 1996, 2002). Gray (2004) introduced a broader definition which was based on the analysis and discussion of different approaches: geodiversity is the natural range (diversity) of geological (rocks, minerals, fossils), geomorphological (land form, processes) and soil features, including their assemblages, relationships, properties, interpretations and systems. Panizza (2009) presented the term "geomorphodiversity" which refers to the diversity of the landforms and processes and can be seen as a subset of geodiversity.

The importance of geodiversity can be represented by multiple values that are important for human activities (Gray, 2004):

- intrinsic value is independent on the human's evaluation, also called scientific value (Panizza, 2001, 2009);

- cultural value is connected to geomythology - an explanation of the geological and geomorphological features using the supernatural forces and beings (Vitaliano, 2007), historical and archaeological aspects of geodiversity (an importance of geodiversity for ancient settlements or fortress systems, e. g. Mesa Verde, USA), spiritual and religious aspects (Gray, 2004);

- aesthetic value refers to visual (and non-visual) appeal provided by geodiversity including a psychological impact on human beings (Gray, 2004; Pereira, 2006). The aesthetic value of geodiversity is also a very important issue for geotouristic activities;

- economic and functional value is represented by the use of mineral resources, e. g. fuels, construction materials; utilisation of landforms, e. g. platforms as a suitable place for airports (Gray, 2004) and utilisation of geodiversity, respectively geoheritage, for geotouristic and geoeducational activities (Reynard, et al., 2003; Pralong, 2003; Panizza \& Piacente, 2008).

- research and educational value that is related to the understanding of the origin of life and landforms, evolution of the landscape and climate and palaeogeographic reconstructions (Gray, 2004; Panizza, 2001).

It is obvious that geodiversity, thanks to its values, has to be conserved and preserved. Maintaining an inventory of geodiversity and its evaluation can serve geoconservation purposes and these can serve as a basis for particular geotourism activities. Geoconservation can be described as an activity of humans which is oriented to the conservation of geoheritage and which aims to preserve the natural diversity of significant geological (bedrock), geomorphological (landform) and soil features and processes, and to maintain natural rates and magnitudes of change in those features and processes (Sharples, 2002). Burek and Prosser (2008) distinguish between the terms "conservation" and "preservation": while preservation can be taken as keeping something in the same state, stopping it from changing; the conservation is an activity or an intent of conserving and enhancing geological and geomorphological features, processes, sites and specimens which also involves working with the natural change to retain the feature of interest.

The geoconservation activities have a long history which is widely described and summarized by Burek and Prosser (2008). Its principles are defined and summarized by 
Sharples (1995), Sharples (2002), Australian Heritage Commission (1996), Australian Heritage Commission (2002), Dingwall et al. (2005), and ProGEO (2011). An overview of the geoconservation principles and practice is given by Brilha (2005) or Prosser, Murphy, and Larwood (2011) who also present the aims of geoconservation and give the guidelines for good practice.

With regard to the needs of present day society, it is not possible to conserve all the geodiversity. Moreover, this concept is very wide and incomprehensible for public (Andrasanu, 2009). Cleal (2007) says that one of the ways how to protect and conserve geodiversity effectively is to protect and conserve its valuable part - geoheritage (geologic and geomorphologic heritage) that can be represented by significant geologic and geomorphologic sites. Therefore, geoconservation should return to a clearer site-based focus, justifying the protection of individual sites at different levels of significance according to their relative scientific importance (Cleal, 2007).

The concept of geoheritage is based on the definition of natural heritage which was presented already in 1972 (UNESCO, 1972). The term geoheritage was defined as those components of natural geodiversity of significant value to humans, including scientific research, education, aesthetics and inspiration, cultural development, and a sense of place experienced by communities (Dixon, 1996, p. 14). A similar definition is presented by Eberhard (1997); he emphasises that geoheritage belongs to the "things we would wish to retain for present and future generations". Sharples (2002) says that geoheritage is represented by those elements of natural geodiversity which are of significant value to humans for non-depleting purposes which do not decrease their intrinsic or ecological values. In addition, it is represented by specific examples of features and processes which are worth of protection and conservation. He also strictly distinguishes between the term "geodiversity" as a value-free quality, and "geoheritage" as those elements of geodiversity that are seen as significant according to particular subjective values (Sharples, 2002).

The concept of geoheritage is linked to the concept of geosites and geomorphosites. The geosites are defined as portions of the geosphere that present a particular importance for the comprehension of Earth history, geological or geomorphological objects that have acquired a scientific, cultural/historical, aesthetic and/or social/economic value due to human perception or exploitation (Reynard, 2004, p. 440); geomorphosites are the landforms to which a value can be attributed and they can be used by society as a geomorphological resource (Panizza, 2001). If these definitions are accepted, then some of the geosites and geomorphosites can be considered as specific examples of geoheritage.

As stated above, the geosites may be considered as a part of the geosphere that presents particular importance for the comprehension of the Earth history and they can be divided into groups according to the prevailing feature, for example sedimentological, stratigraphical, volcanic, geomorphological, petrographical or mining (Reynard, 2004, p. 440). In some German and some French speaking countries, the term "geotop" is used (Grube \& Wiedenbein, 1992; Grandgirard, 1997). Concerning the evaluation of geosites, Reynard, Coratza, and Regolini-Bissig (2009) indicate that it should be based 
essentially on scientific criteria (rarity, exemplarity, or importance for Earth history understanding etc.).

Geomorphosites can be considered as one of the multiple types of the geosites and they are defined as landforms that have acquired a value thanks to human perception (Panizza, 2001). These values were divided into two groups which are described as follows (Reynard, Coratza, \& Regolini-Bissig, 2009):

1) Scientific values that present an importance for understanding of a form, process or evolution. Within the geomorphologic sites, the representativeness of the form and process, uniqueness and palaeogeographical significance of the site are considered one of the most important scientific values. Panizza (2001), Coratza and Giusti (2005), and Reynard, et al. (2007) discuss these values in detail and they also offer how to assess the scientific value of the sites.

2) Additional values include cultural, aesthetic, ecological and economic/social values. The cultural value is represented by the archaeological or historic significance of the site which is somehow related to the geological and geomorphological features and processes of the site - the importance of cultural value for geomorphosite assessment and the relations between geomorphosites and their cultural aspects are analysed by Piacente (2005), and Panizza and Piacente (2005). The aesthetic value is based on the colour contrast, the structure of the space or heterogeneity of the site. For these facts it is the most problematic value to describe. The economic or social value is related to the potential for the use of the site especially for geotourism; the exploitation of geosites and geomorphosites, especially for tourism activities, is discussed by Reynard, et al. (2003), Pralong and Reynard (2005), Panizza and Piacente (2008). The ecological value of the site expresses the relation between geomorphologic elements of the site and biota and the influence of geomorphosite on the development of an ecosystem; it can also include the presence of specific or rare species or biodiversity value (Reynard, et al., 2007). Added values are also analysed by Pereira, et al. (2007). Bruschi and Cendrero (2005) discuss these values and they propose a method how to "measure" intangible values. Pralong (2005) focuses on economic, respectively tourist values of the sites and he presents particular criteria for the assessment of economic value and tourist potential (see below).

As the geomorphosites acquire both scientific and an added value, the evaluation of them is not restricted only to the scientific criteria, but also to the criteria that are related to cultural, scenic, social or economic features (e. g. visibility, accessibility, presence of cultural assets), in order to better meet the requirements of geotourism.

The research on geomorphosites is relatively young. In 2001, the working group Geomorphosites by the International Association of Geomorphologists was established and it started to deal with definition, methodology and assessment methods. The working group emphasises interdisciplinary research and cooperation with other geoconservation and geotourism initiatives, especially geoparks (Giusti, 2010).

Theoretical aspects of geomorphosites were discussed by Panizza (2001), Reynard (2005), Panizza and Piacente (2005). The relationship between geomorphosites and education was analyzed by Pralong (2003). Assessment methods were presented (e. g. 
Coratza \& Giusti, 2005; Bruschi \& Cendrero, 2005; Pralong, 2005; Serrano \& GonzalezTrueba, 2005; Pereira, et al., 2007; Reynard, et al., 2007; Zouros, 2007). These methods were applied in different regions and conditions - different case studies especially from Italy, Portugal, Switzerland or Greece were presented at the monothematic issues of Il Quaternario - Italian Journal of Quaternary Sciences, Vol. 18, No. 1 (2005), Géomorphologie: relief, processus, environment, Vol. 1, No. 3 (2005), Geographica Helvetica, Vol. 62, No. 3 (2007), Geoheritage, Vol. 3, No. 3 (2010). In the Eastern Europe, the geomorphosite assessment was done e. g. in Romania (Ilies \& Josan, 2007; Ilies, et al., 2009; Comanescu \& Dobre, 2009; Comanescu, et al., 2009), Serbia (Vujicic, et al., 2011), Slovenia (Erhartič, 2010) or Czech Republic (Kubalíková, 2011).

Theoretical issues, methodological approaches and case studies are summarized in Reynard, Coratza, and Regolini-Bissig (2009).

\section{Assessment methods}

There are two main approaches to assessment of geosites and geomorphosites: the first one is based on the expertise and qualitative procedures and the second one is related to the need to rank the sites, to assess the site numerically and to detect the potential of the site (Pereira and Pereira, 2010). Since 1990's various assessment methods for geosites were introduced, e. g. Panizza and Piacente (1993), Barba, et al. (1997), Grandgirard (1999), or Reynolds (2001). These methods were focused mainly on the scientific value of the geosites and some of them did not include the added values that are important for geotourism activities although the criteria served as a base or inspiration for more complex assessment methods.

Later, within the concept of geomorphosites, other assessment methods were presented. These methods generally include both scientific and added values, so they can serve better for geotourism purposes or for assessment of the tourist potential of the sites. Coratza and Giusti (2005) presented a method for determining the natural or scientific values of geomorphological sites, but they also included added values. Bruschi and Cendrero (2005) presented a method how to assess or measure intangible values of geomorphosites. Pralong (2005) presented a methodology that can be used in assessing a tourist potential of the geomorphological sites. Serrano and González-Trueba (2005), Zouros (2005), and Zouros (2007) introduced an assessment methodology that can be used for evaluation of the geomorphosites in protected areas. Reynard, et al. (2007), and Pereira, et al. (2007) also presented the assessment methodologies for assessing scientific and added values. Later, Pereira and Pereira (2010) introduced an assessment methodology for potential geomorphosites.

All the methods mentioned above are numerical; the numerical assessment has an advantage of relative objectivity, but even there are certain parameters that can be measured with difficulties and could be the source of disagreements. Another problem of the assessment process is subjectivity, especially in the evaluation of aesthetic and cultural aspects of the site, but also in the evaluation of the scientific significance of the site. 
Generally, the assessment is divided into several steps: assessment of scientific values, assessment of added values (sometimes it includes an assessment of the tourist potential or assessment of economic values, sometimes these are assessed independently) and assessment of vulnerability, threats and risk on the site. It is necessary to underline that assessment has to be done on the basis of knowledge and existing detailed inventory of the potential geosites and geomorphosites.

The assessment of scientific values is based on criteria which are connected to the intrinsic value of the site (Gray, 2004; Panizza, 2009) and the assessing criteria are represented e. g. by integrity or rarity. Some authors include also exemplarity or pedagogical value (Pereira, et al., 2007) or scientific knowledge of the site (Coratza \& Giusti, 2005; Bruschi \& Cendrero, 2005).

The assessment of the added values is based on the cultural/historical/religious/ aesthetic aspects that are connected to the site. These values are generally less precise and depend on the sensitivity of the assessor but they are also essential for the complete assessment (Pereira \& Pereira, 2010). While the cultural/historical/religious criteria usually consist only of the information about the level of importance of these assets (e. g. Coratza \& Giusti, 2005), the assessment of aesthetic or scenic aspect is more complicated and can be influenced by subjectivity. The assessment criteria for the aesthetic value are generally based on the visibility and number of viewpoints and colour contrast with surrounding (Pralong, 2005; Reynard, et al., 2007), vertical structure or number of colours (Pereira, et al., 2007).

The assessment of the economic value or potential for the use is generally based on the criteria like accessibility, limitations of use and existence of infrastructure (Serrano \& Gonzalez-Trueba, 2005) or existence of economic and supporting products related to the site or promotion of the site (Pralong, 2005; Reynard, et al., 2007).

Some methods include the assessment of vulnerability and both natural and anthropogenic threats to the site (e. g. Pereira, et al., 2007). The assessment criteria are represented by the existing legislative protection of the site or present and potential threats (Zouros, 2007).

The following section presents the selected assessment methods.

\section{University of Modena, Italy}

Panizza (2001) introduced an assessment methodology which was originally used for the purposes of Environmental Impact Assessment. The methodology was later developed by Coratza and Giusti (2005). Although the authors emphasize that the "geomorphosite" has both scientific and added values (cultural, historical etc.), the assessment methodology is oriented on scientific parameters of the site and added values form only a small part of the assessment. The assessment is based on seven characteristics:

- value for the scientific research (based on number of the scientific papers, importance of geomorphosite for paleogeographical reconstructions, includes also number and importance of publication); 
- educational value (representativeness of a particular form or process, quotation in educative textbooks);

- area (the greater the geomorphosite is, the higher is its value);

- rareness (quantity of similar sites within the territory under investigation);

- integrity (both natural and anthropogenic degree of degradation affecting the site);

- exposure (visibility, presence of human structures which can disturb the sight);

- added values (including tourism-economic, historical-cultural or ecological characteristics).

The overall value of the site is represented by weighted mean where weights range from 0 to 1 . This method was applied to the inventory of the geomorphosites in the Modena region in Italy originally for the Environmental Impact Assessment (EIA) and territorial planning (Coratza \& Giusti, 2005).

\section{University of Cantabria, Spain}

Bruschi and Cendrero (2005) introduced a method based on three groups of criteria: intrinsic (scientific) quality of sites, the potential for use (economic value) and potential threats and protection needs. Every group consists of several criteria (Table 1).

Table 1 Assessment criteria according to Bruschi and Cendrero (2005)

\begin{tabular}{|l|l|l|}
\hline Intrinsic quality & $\begin{array}{l}\text { Potential for use (social } \\
\text { usefulness) }\end{array}$ & $\begin{array}{l}\text { Potential threats } \\
\text { and protection needs }\end{array}$ \\
\hline Abundance/rarity & $\begin{array}{l}\text { Activities that can be } \\
\text { carried out }\end{array}$ & Inhabitants in the surroundings \\
\hline Degree of scientific knowledge & Observation conditions & Present or potential threats \\
\hline $\begin{array}{l}\text { Usefulness as a process model/ } \\
\text { example }\end{array}$ & Accessibility & Possibility to collect objects \\
\hline $\begin{array}{l}\text { Diversity of elements } \\
\text { of interest }\end{array}$ & Extent & $\begin{array}{l}\text { Relationship to the existing } \\
\text { planning }\end{array}$ \\
\hline Age & Proximity to service centres & Interest for mineral exploitation \\
\hline $\begin{array}{l}\text { Type locality } \\
\text { of the area }\end{array}$ & Land ownership \\
\hline Integrity & $\begin{array}{l}\text { Socio-economic condition } \\
\text { archaeological, artistic heritage }\end{array}$ & \\
\hline $\begin{array}{l}\text { Association with other natural } \\
\text { heritage }\end{array}$ & & \\
\hline
\end{tabular}

Source: adapted from Reynard, Coratza, and Regolini-Bissig (2009), Bruschi and Cendrero (2005) 
The method was used for EIA and regional inventory in the Province of Cantabria in Spain (Bruschi, 2007). Although some parameters are disputatious, e. g. age and extent of the site (the older/greater a site is, the higher is its value) or the importance of socioeconomic condition of the area and relatively a little emphasis is put on the cultural and historical values (they are included in scientific quality of the site), other criteria can be used for assessing the sites from the geotourist point of view.

\section{University of Valladolid, Spain}

Serrano and Gonzalez-Trueba (2005) proposed a methodology based on three categories of assessment criteria (Table 2).

Table 2 Assessment criteria according to Serrano and Gonzalez-Trueba (2005)

\begin{tabular}{|l|l|l|}
\hline Scientific value & Added values & Use/management value \\
\hline genesis & landscape and aesthetic & accessibility \\
\hline morphology & cultural & fragility \\
\hline dynamics & educational value & vulnerability \\
\hline chronology & representativeness & intensity of use \\
\hline lithology & tourist attraction & risk of degradation \\
\hline geologic structures & & integrity \\
\hline sedimentary structures & & impacts \\
\hline & & conditions for observation \\
\hline & & limits of acceptable change \\
\hline
\end{tabular}

Source: adapted from Serrano and Gonzalez-Trueba (2005)

The methodology was used for the assessment of geomorphosites in Picos de Europa National Park (Serrano \& Gonzalez-Trueba, 2005). The method is good for assessing the scientific values and management values. Some of the added values (especially landscape aesthetic) are very subjective and the cultural/historic value is not very appreciated in this method. 


\section{University of the Aegean}

Zouros $(2005,2007)$ proposed an evaluation process based on the following criteria (Table 3).

Table 3 Assessment criteria according to Zouros (2007)

\begin{tabular}{|l|l|}
\hline \multirow{4}{*}{ Value } & Criteria \\
\hline \multirow{4}{*}{ geontific and educational value } & integrity \\
\cline { 2 - 2 } & representativeness \\
\cline { 2 - 2 } & rarity \\
\cline { 2 - 2 } & exemplarity \\
\hline ecological and aesthetic value & number of phenomena within area \\
\hline \multirow{2}{*}{ potential threats and protection } & presence of the natural heritage sites or nature reserves \\
\hline potential for use & legal protection \\
\cline { 2 - 2 } & vulnerability \\
\hline & recognizability \\
\cline { 2 - 2 } & geographical distribution \\
\cline { 2 - 2 } & accessibility \\
\cline { 2 - 2 } & economical potential \\
\hline
\end{tabular}

Source: adapted from Zouros (2007)

This method was used for assessing the geomorphosites in the Aegean Area and within the geopark Lesvos Petrified Forest (now Lesvos geopark) (Zouros, 2005, 2007). It allows a quick overview of the values that are held by geomorphosites and includes all the necessary criteria, but there is not big emphasis on the economic value of the geomorphosites.

\section{Pralong (2005)}

Pralong (2005) proposed a complex method that was primarily oriented to assess the tourist potential of the geomorphosites. The method is detailed and aimed especially at the economic values of the sites, but scientific, cultural and scenic parameters are not oppressed.

The tourist value assessment includes four main values: scenic, scientific, cultural and economic and is considered as the mean of these four different values. The criteria for the assessment are shown in Table 4. 
Table 4 Assessment criteria according to Pralong (2005)

\begin{tabular}{|l|l|l|l|}
\hline \multicolumn{1}{|c|}{ Scenic value } & \multicolumn{1}{|c|}{ Scientific value } & \multicolumn{1}{c|}{ Cultural value } & Economic value \\
\hline $\begin{array}{l}\text { number of } \\
\text { viewpoints }\end{array}$ & $\begin{array}{l}\text { paleogeographic } \\
\text { interest }\end{array}$ & $\begin{array}{l}\text { cultural and historical } \\
\text { customs }\end{array}$ & accessibility \\
\hline $\begin{array}{l}\text { average distance } \\
\text { to the viewpoints }\end{array}$ & representativeness & iconographic presentation & natural risks \\
\hline surface & area & $\begin{array}{l}\text { historical and archaeological } \\
\text { relevance }\end{array}$ & $\begin{array}{l}\text { annual number of } \\
\text { visitors }\end{array}$ \\
\hline elevation & rarity & $\begin{array}{l}\text { religious and metaphysical } \\
\text { relevance }\end{array}$ & $\begin{array}{l}\text { official level of } \\
\text { protection }\end{array}$ \\
\hline color contrasts & integrity & art and cultural events & attraction \\
\hline & ecological interest & & \\
\hline
\end{tabular}

Source: adapted from Pralong, 2005

Another step in this method is the "exploitation value" assessment that includes two components: a degree of exploitation and modality of exploitation. The degree of exploitation considers the spatial and temporal use of a geomorphological site (based on the criteria such as used surface, infrastructure, seasonal occupancy), whereas the modality takes into account the use of the four constituent values (use of scenic, scientific, cultural and economic values) of the tourist value of the geomorphological site. This method is probably the best and most complex from the point of view of geotourism needs. However, some parameters are not easy to achieve (total number of visitors or iconographic presentations of the site).

\section{University of Minho, Portugal}

Pereira, et al. (2007) proposed a very detailed assessment procedure based on the scientific, additional, use and protection values. The methodology was then developed by Pereira and Pereira (2010). Table 5 shows the parameters.

Table 5 Assessment criteria according to Pereira, et al. (2007)

\begin{tabular}{|l|l|l|l|}
\hline \multicolumn{1}{|c|}{ Scientific value } & Additional values & \multicolumn{1}{c|}{ Use value } & Protection value \\
\hline Rareness in relation to the area & Cultural value & Accessibility & Integrity/Intactness \\
\hline Integrity/Intactness & Aesthetic value & Visibility & $\begin{array}{l}\text { Vulnerability of use } \\
\text { as a geomorphosite }\end{array}$ \\
\hline $\begin{array}{l}\text { Representativeness of } \\
\text { geomorphological processes } \\
\text { and pedagogical interest }\end{array}$ & Ecological value & $\begin{array}{l}\text { Present use of the } \\
\text { geomorphological } \\
\text { interest }\end{array}$ & \\
\hline
\end{tabular}




\begin{tabular}{|l|l|l|l|}
\hline \multicolumn{1}{|c|}{ Scientific value } & Additional values & \multicolumn{1}{c|}{ Use value } & Protection value \\
\hline $\begin{array}{l}\text { Number of interesting } \\
\text { geomorphological features }\end{array}$ & $\begin{array}{l}\text { Present use of } \\
\text { other natural and } \\
\text { cultural interests }\end{array}$ & \\
\hline $\begin{array}{l}\text { Other geological features } \\
\text { with the heritage value }\end{array}$ & $\begin{array}{l}\text { Legal protection } \\
\text { and use limitations }\end{array}$ & \\
\hline $\begin{array}{l}\text { Scientific knowledge of } \\
\text { geomorphological issues }\end{array}$ & $\begin{array}{l}\text { Equipment and } \\
\text { support services }\end{array}$ & \\
\hline Rareness at national level & & & \\
\hline
\end{tabular}

Source: Pereira, et al. (2007)

The method was used in the Minho National Park for assessing the geosites and geomorphosites (Pereira, 2006; Pereira, et al., 2007). This method is probably one of the most complex with regards to assessing the geotourism values and potential for geotourism.

\section{University of Lausanne, Switzerland}

Reynard et al. (2007) emphasizes that every assessment should be based on the detailed inventory and field work that include general data and description data (morphology, genesis). The assessment criteria are presented in Table 6 .

Table 6 Assessment criteria according to Reynard, et al. (2007)

\begin{tabular}{|l|l|}
\hline Value & Criteria \\
\hline \multirow{5}{*}{ scientific value } & integrity \\
\cline { 2 - 2 } & representativeness \\
\cline { 2 - 2 } & paleogeographical value \\
\cline { 2 - 2 } & rareness \\
\hline ecological value & ecological impact \\
\cline { 2 - 2 } & protected species \\
\hline aesthetic values & number of viewpoints \\
\cline { 2 - 2 } & contrasts, vertical development \\
\hline cultural value & religious importance \\
\cline { 2 - 2 } & historical importance \\
\cline { 2 - 2 } & artistic importance \\
\hline economic value & economic products \\
\hline
\end{tabular}

Source: Reynard, et al. (2007) 
This method can be used for scientific and added values assessment. However, the economic value is represented only by one criterion, therefore for geotourism purposes it is not very suitable.

\section{Results}

To find out which method is suitable for the geotourism purposes, it is necessary to take into account the definitions and principles of geotourism (see Table 7). Geotourism can be understood at a broader sense as geographical tourism or tourism that sustains or enhances the geographical character of a place - its environment, culture, aesthetics, heritage, and the wellbeing of its residents (Stueve, et al., 2002; National Geographic Society, 2005). This concept is similar to the geomorphosite concept - it does not include only the abiotic features, but it takes into account cultural and aesthetic values (Panizza \& Piacente, 2008; Reynard, 2008). In a more restricted sense, the geotourism is defined as a form of nature tourism that specifically focuses on landscape and geology (Dowling \& Newsome, 2006) and that includes the provision of interpretative and service facilities for geosites and geomorphosites and their encompassing topography, together with their associated in-situ and ex-situ artefacts, to constituency-build for their conservation by generating appreciation, learning and research by and for current and future generations (Hose, 2012).

Table 7 The overview of the definitions of geotourism

\begin{tabular}{|l|l|}
\hline Hose (1995) & $\begin{array}{l}\text { The provision of interpretive and service facilities to } \\
\text { enable tourists to acquire knowledge and understanding } \\
\text { of the geology and geomorphology of a site (including its } \\
\text { contribution to the development of the Earth sciences) } \\
\text { beyond the level of mere aesthetic appreciation. }\end{array}$ \\
\hline Hose (2000) & $\begin{array}{l}\text { The provision of interpretative facilities and services to } \\
\text { promote the values and social benefit of geologic(al) and } \\
\text { geomorphologic(al) sites and their materials, and to ensure } \\
\text { their conservation for the use of students, tourists and casual } \\
\text { recreationalists. }\end{array}$ \\
\hline $\begin{array}{l}\text { Slomka and Kicinska- } \\
\text { Swiderska (2004) }\end{array}$ & $\begin{array}{l}\text { An offshoot of cognitive tourism and/or adventure tourism } \\
\text { based upon visits to geological objects (geosites) and } \\
\text { recognition of geological processes integrated with aesthetic } \\
\text { experiences gained by the contact with a geosite. }\end{array}$ \\
\hline National Geographic (2005) & $\begin{array}{l}\text { Tourism that sustains or enhances the geographical character } \\
\text { of a place - its environment, culture, aesthetics, heritage, and } \\
\text { the well-being of its residents. }\end{array}$ \\
\hline Joyce (2006) & $\begin{array}{l}\text { People going to a place to look at and learn about one or } \\
\text { more aspects of geology and geomorphology. }\end{array}$ \\
\hline
\end{tabular}




\begin{tabular}{|l|l|}
\hline Dowling and Newsome (2006) & $\begin{array}{l}\text { Tourism relating specifically to geology and geomorphology } \\
\text { and the natural resources of landscape, landforms, fossil } \\
\text { beds, rocks and minerals, with an emphasis on appreciating } \\
\text { the processes that are creating and created such features. }\end{array}$ \\
\hline Hose (2008) & $\begin{array}{l}\text { The provision of interpretive and service facilities to enable } \\
\text { tourists to acquire knowledge and the understanding of } \\
\text { the geology and geomorphology of the site (including its } \\
\text { contribution to the development of the Earth sciences) } \\
\text { beyond the level of mere aesthetic appreciation. }\end{array}$ \\
\hline Newsome and Dowling (2010) & $\begin{array}{l}\text { A form of nature tourism that specifically focuses on } \\
\text { landscape and geology. It promotes tourism to the geosites } \\
\text { and the conservation of geodiversity and an understanding } \\
\text { of Earth sciences through appreciation and learning. This is } \\
\text { achieved through independent visits to geological features, } \\
\text { use of geo-trails and view points, guided tours, geo-activities } \\
\text { and patronage of geosite visitor centres. }\end{array}$ \\
\hline Hose (2012) & $\begin{array}{l}\text { The provision of interpretative and service facilities for the } \\
\text { geosites and geomorphosites and their encompassing } \\
\text { topography, together with their associated in-situ and ex- } \\
\text { situ artifacts, to constituency-build for their conservation by } \\
\text { generating appreciation, learning and research by and for } \\
\text { current and future generations. }\end{array}$ \\
\hline
\end{tabular}

Source: adapted from Newsome and Dowling (2010), Hose $(2008,2012)$

Both broader and more restricted definitions include some key features of geotourism. According to the National Geographic Society (2005), they are represented by integrity of place, international codes, market selectivity and diversity, tourist satisfaction, community involvement and benefit, protection and enhancement of destination appeal, land use and planning, conservation of resources, interactive interpretation and evaluation; according to (Newsome \& Dowling, 2010): geologically based, environmentally educative, tourist satisfaction, sustainable, locally beneficial.

Based on these definitions and principles, the criteria for the selection of the suitable assessment method can be proposed.

A suitable method for assessing the geotourism potential should consider these groups of criteria:

1. Criteria which consider an assessment of the scientific and intrinsic values (diversity and importance of geological and geomorphological features and processes, the scientific knowledge of the site) - based on the principles "geologically based" and "integrity of place" and geology and geomorphology - oriented definitions of geotourism (Newsome \& Dowling, 2010). 
2. Criteria which consider an assessment of the exemplarity and pedagogical potential of the site (clarity and visibility of geological and geomorphological features and processes, the availability of the products that support education: leaflets, guided tours, maps, trails, information panels, information centres) - based on the principles "environmentally educative", "protection and enhancement of destination appeal ", "interactive interpretation and evaluation". This is probably the most important group of criteria as the education or cognitive aspects appear in most of the definitions of geotourism.

3. Criteria which consider an assessment of accessibility and visibility of the site and the presence of tourist infrastructure (accommodation, restaurants, shops, local products etc.) - based on the principles "tourist satisfaction", "tourist satisfaction", "locally beneficial", "market selectivity and diversity", "community involvement and benefit". It is also a very important group of criteria as the new definitions and new approaches (Newsome \& Dowling, 2010; Hose, 2012) emphasize the involvement of local people. This approach is also a basis for geoparks (Zouros, 2013, oral presentation).

4. Criteria which consider an assessment of the existing threats and risks, assessing conservation activities or existing legislative protection of the site - according to the principle "sustainable", "land use and planning" and "conservation of resources".

5. Criteria which consider an assessment of the added values (ecological, cultural, historic, archaeological, artistic, religious value of a site, aesthetic, landscape and scenic value) - according to the definition of the National Geographic Society (2005) the geotourism does not consider only the natural aspects, but also cultural and aesthetic aspects of the site.

The proposed criteria for determining the suitability of the method for assessing the geosites and geomorphosites for geotourism purposes are presented in Table 8.

Table 8 Individual criteria within the above mentioned groups of criteria

\begin{tabular}{|c|c|}
\hline \multirow[t]{3}{*}{$\begin{array}{l}\text { 1. assessment of the scientific } \\
\text { and intrinsic values }\end{array}$} & $\begin{array}{l}\text { 1.a assessing integrity, rarity and Earth-science importance of } \\
\text { the site }\end{array}$ \\
\hline & 1.b assessing scientific knowledge of the site \\
\hline & 1.c assessing morphology, genesis, age, diversity of the site \\
\hline \multirow{3}{*}{$\begin{array}{l}\text { 2. assessment of the } \\
\text { exemplarity and } \\
\text { pedagogical potential }\end{array}$} & $\begin{array}{l}\text { 2.a assessing the exemplarity and representativeness of the } \\
\text { site, clarity and visibility of the features and processes }\end{array}$ \\
\hline & $\begin{array}{l}\text { 2.b assessing presence of educational facilities (leaflets, web } \\
\text { pages, information panels, guided tours) }\end{array}$ \\
\hline & $\begin{array}{l}\text { 2.c assessing the degree of the use of the site for educational } \\
\text { purposes }\end{array}$ \\
\hline
\end{tabular}




\begin{tabular}{|l|l|}
\hline $\begin{array}{l}\text { 3. assessment of accessibility } \\
\text { and visibility of the site } \\
\text { and the presence of tourist } \\
\text { infrastructure }\end{array}$ & $\begin{array}{l}\text { 3.a assessment of number, distance and quality of tourist } \\
\text { services }\end{array}$ \\
\cline { 2 - 2 } & $\begin{array}{l}\text { 3.b assessment of the presence of local products that } \\
\text { support and/or promote the site }\end{array}$ \\
\cline { 2 - 3 } & 3.c assessment of accessibility \\
\hline $\begin{array}{l}\text { 4. assessment of the existing } \\
\text { threats and risks, assessing } \\
\text { conservation activities or the } \\
\text { existing legislative protection } \\
\text { of the site }\end{array}$ & $\begin{array}{l}\text { 4.a assessment of the conservation activities (legal } \\
\text { protection, other types of protection) }\end{array}$ \\
\hline & 4.b assessment of the risks and threats to the site \\
\hline 2. assessment of added values & $\begin{array}{l}\text { 4.c assessment of current status of the site, the level of } \\
\text { disturbance or degradation }\end{array}$ \\
\hline & $\begin{array}{l}5 . a \text { assessment of cultural (historical/religious/archaeological) } \\
\text { values }\end{array}$ \\
\hline & $\begin{array}{l}5 . b \text { assessment of ecological value (relationships to living } \\
\text { nature) }\end{array}$ \\
\hline & 5.c assessment of aesthetic/landscape/scenic value \\
\hline
\end{tabular}

Source: author (2013)

The following section (Table 9) tries to evaluate the above mentioned geomorphosite assessment methods in terms of suitability for assessing the geosites and geomorphosites for geotourism purposes. For every criterion, a value is added ( 1 - the method considers the criterion, 0.5 - the method partly considers the criterion, 0 - the method does not consider the criterion).

Table 9 The numerical assessment of the selected methods

\begin{tabular}{|l|c|c|c|c|c|c|c|}
\hline $\begin{array}{l}\text { Particular criterion / } \\
\text { method }\end{array}$ & $\begin{array}{c}\text { Coratza, } \\
\text { Giusti } \\
(2005)\end{array}$ & $\begin{array}{c}\text { Bruschi, } \\
\text { Cendrero } \\
(2005)\end{array}$ & $\begin{array}{c}\text { Serrano, } \\
\text { Gonzalez } \\
(2005)\end{array}$ & $\begin{array}{c}\text { Zouros } \\
(2007)\end{array}$ & $\begin{array}{c}\text { Pralong } \\
(2005)\end{array}$ & $\begin{array}{c}\text { Pereira et } \\
\text { al. (2007) }\end{array}$ & $\begin{array}{c}\text { Reynard } \\
\text { et al. } \\
(2007)\end{array}$ \\
\hline 1.a integrity, rarity & 1 & 1 & 1 & 1 & 1 & 1 & 1 \\
\hline 1.b scientific knowledge & 1 & 1 & 1 & 0 & 0 & 1 & 0 \\
\hline 1.c morphology, genesis & 0 & 1 & 1 & 0 & 0 & 1 & 0 \\
\hline 2.a exemplarity, clarity & 1 & 1 & 1 & 1 & 1 & 1 & 1 \\
\hline 2.b educational facilities & 0 & 0 & 0 & 0 & 1 & 1 & 0 \\
\hline 2.c use for education & 0 & 1 & 0 & 0 & 1 & 1 & 0 \\
\hline 3.a tourist services & 0 & 1 & 0.5 & 1 & 1 & 1 & 0 \\
\hline 3.b local products & 0 & 0.5 & 0.5 & 0.5 & 1 & 0.5 & 1 \\
\hline
\end{tabular}




\begin{tabular}{|l|c|c|c|c|c|c|c|}
\hline $\begin{array}{l}\text { Particular criterion / } \\
\text { method }\end{array}$ & $\begin{array}{c}\text { Coratza, } \\
\text { Giusti } \\
(2005)\end{array}$ & $\begin{array}{c}\text { Bruschi, } \\
\text { Cendrero } \\
(2005)\end{array}$ & $\begin{array}{c}\text { Serrano, } \\
\text { Gonzalez } \\
(2005)\end{array}$ & $\begin{array}{c}\text { Zouros } \\
(2007)\end{array}$ & $\begin{array}{c}\text { Pralong } \\
(2005)\end{array}$ & $\begin{array}{c}\text { Pereira et } \\
\text { al. (2007) }\end{array}$ & $\begin{array}{c}\text { Reynard } \\
\text { et al. } \\
(2007)\end{array}$ \\
\hline 3.c accessibility & 1 & 1 & 1 & 1 & 1 & 1 & 0 \\
\hline 4.a conservation activities & 0 & 1 & 1 & 1 & 1 & 1 & 0 \\
\hline 4.b risks and threats & 1 & 1 & 1 & 1 & 1 & 1 & 0 \\
\hline 4.c current status & 1 & 1 & 1 & 0 & 1 & 1 & 1 \\
\hline 5.a cultural values & 0.5 & 0.5 & 1 & 1 & 1 & 1 & 1 \\
\hline $\begin{array}{l}\text { 5.b ecological value } \\
\text { 5.c aesthetic/landscape } \\
\text { value }\end{array}$ & 0.5 & 1 & 0 & 1 & 1 & 1 & 1 \\
\hline Total score & 0.5 & 0 & 1 & 1 & 1 & 1 & 1 \\
\hline
\end{tabular}

Source: author (2013)

The less relevant methods for assessing the geosites and geomorphosites for geotourism purposes are the method of the University of Modena (Coratza \& Giusti, 2005) and the University of Lausanne (Reynard, et al., 2007). The Italian method covers partly the first group of criteria (assessment of the scientific and intrinsic values), the fourth group of criteria (assessment of the existing threats and risks, assessing conservation activities or the existing legislative protection of the site) and the fifth group of criteria (assessment of added values), but it does not include the criteria for assessing the educational potential (only the criterion "representativeness" appears) and criteria for the assessment of accessibility and visibility of the site and the presence of tourist infrastructure (it only includes "tourist-economic value" which is very unclear to assess). The method of the University of Lausanne covers the fifth group of criteria (added values), but other groups are covered only partly.

The method which was introduced by Zouros (2007) can serve well for the assessment of the added values and economic values (assessment of accessibility and visibility of the site and the presence of tourist infrastructure) and partly for the conservation values (fourth group), but for assessing the scientific and educational value it is not suitable.

The methods of Serrano and Gonzalez-Trueba (2005), and Bruschi and Cendrero (2005) are more suitable for the geotourism purposes and they are good for assessing the scientific and conservation values (both methods fully include the criteria) and also for the economic values. The added values are somewhat neglected, but still are included in both methods. Serrano and Gonazez-Trueba's method does not cover ideally the educational values.

The method of Pralong (2005) covers almost all the criteria with an exception of the first group of criteria (scientific and intrinsic values) and the method of Pereira (2007) includes all the necessary criteria.

According to this simple numerical evaluation of various assessment methods, it can be stated that the less suitable methods for assessing the geosites and geomorphosites 
for geotourism purposes are those of Coratza and Giusti (2005), and Reynard, et al. (2007) and the methods of Pralong (2005), and Pereira (2007) are the most suitable for the geotourism purposes.

Based on the analysis of the principles and definitions of geotourism and numerical evaluation of the methods, the method for assessing the geosites and geomorphosites for the geotourism purposes can be proposed. It is clear that integrity, diversity and rarity of abiotic features should be represented as one of the criteria to consider the scientific and the intrinsic value of the site. The scientific knowledge should be also comprised because it creates the background for educational activities and it helps to raise awareness of the geosites and geomorphosites. The information about morphology, genesis and age should be included in the scientific knowledge.

As most of the definitions of geotourism include the education and promotion of the geosites and geomorphosites to the public as one of the most important aspect of geotourism, the "educational" criteria should be also present. The criteria, such as exemplarity, clarity of the features and processes should be considered. Furthermore, the existence of the supporting products of geoeducation should be included (leaflets, information panels, trails, visitor centres etc.). It should include both the existing products and proposals for these products or possibility to introduce these products (it is dependent especially on the exemplarity or the representativeness of the site).

A group of economic values can be assessed with the criteria which include accessibility to the site (on foot, by car, by public transport, possibility of parking etc.), presence of tourist facilities (accommodation, restaurants, shops) and the existence of local products that are related to the site. It fulfils both "tourist satisfaction" principle of geotourism and "community involvement and benefit" which are both included in the definitions of Newsome and Dowling (2010) and the National Geographic Society (2005).

The conservation is also considered as one of the principles of modern geotourism. Therefore, the analysis of threats (both actual and potential, both natural and anthropogenic) should be included. Also, the analysis of the current status of the site should be assessed (damage of the site, its possible degradation).

The added values are important to the holistic approach to geotourism. Thus, the cultural, ecological and aesthetic values should be also considered, because they can raise the overall value of the site and they can create other opportunities how to relate the abiotic features and processes to biotic or cultural issues. The aesthetic value is also important for the tourist satisfaction, although it is quite difficult to assess this value.

Table 10 presents the proposed method for the geosites and geomorphosites assessment for the geotourism purposes. It is based on the geomorphosite concept, analysis of the selected geomorphosite assessment methods (Coratza \& Giusti, 2005; Bruschi \& Cendrero, 2005; Serrano \& Gonzalez-Trueba, 2005; Pralong, 2005; Reynard, et al., 2007; Pereira, et al, 2007; Zouros, 2007) and on the definitions and principles of geotourism. Some of the criteria are based on Kubalíková (2011). 
Table 10 A method for the geosite and geomorphosite assessment for the geotourism purposes

\begin{tabular}{|c|c|}
\hline \multicolumn{2}{|l|}{ Scientific and intrinsic values } \\
\hline \multirow[t]{3}{*}{ integrity } & 0 - totally destroyed site, \\
\hline & 0.5 - disturbed site, but with visible abiotic features, \\
\hline & 1 - site without any destruction \\
\hline \multirow[t]{3}{*}{ rarity (number of similar sites) } & 0 - more than 5 sites, \\
\hline & 0.5 - $2-5$ similar sites, \\
\hline & 1 - the only site within the area of interest \\
\hline \multirow{3}{*}{$\begin{array}{l}\text { diversity (number of different } \\
\text { partial features and processes } \\
\text { within the geosite or } \\
\text { geomorphosite) }\end{array}$} & 0 - only one visible feature/processes, \\
\hline & $0.5-2-4$ visible features/processes, \\
\hline & 1 - more than 5 visible features/processes \\
\hline \multirow[t]{3}{*}{ scientific knowledge } & 0 - unknown site, \\
\hline & 0.5 - scientific papers on national level, \\
\hline & $\begin{array}{l}1 \text { - high knowledge of the site, monographic studies about } \\
\text { the site }\end{array}$ \\
\hline \multicolumn{2}{|l|}{ Educational values } \\
\hline \multirow{3}{*}{$\begin{array}{l}\text { representativeness and } \\
\text { visibility/clarity of the features/ } \\
\text { processes }\end{array}$} & 0 - low representativeness/clarity of the form and process, \\
\hline & 0.5 - medium representativeness, especially for scientists, \\
\hline & $\begin{array}{l}1 \text { - high representativeness of the form and process, also for } \\
\text { the laic public }\end{array}$ \\
\hline \multirow[t]{2}{*}{ exemplarity, pedagogical use } & $\begin{array}{l}0 \text { - very low exemplarity and pedagogical use of the form } \\
\text { and process, } 0.5 \text { - existing exemplarity, but with limited } \\
\text { pedagogical use, }\end{array}$ \\
\hline & $\begin{array}{l}1 \text { - high exemplarity and high potential for pedagogical use, } \\
\text { goedidactics and geotourism }\end{array}$ \\
\hline \multirow[t]{3}{*}{ existing educational products } & 0 - no products, \\
\hline & 0.5 - leaflets, maps, web pages, \\
\hline & 1 - info panel, information at the site \\
\hline \multirow{3}{*}{$\begin{array}{l}\text { actual use of a site for } \\
\text { educational purposes } \\
\text { (excursions, guided tours) }\end{array}$} & 0 - no educative use of the site, \\
\hline & 0.5 - site as a part of specialized excursions (students), \\
\hline & 1 - guided tours for public \\
\hline \multicolumn{2}{|l|}{ Ecomonical values } \\
\hline \multirow[t]{3}{*}{ accessibility } & 0 - more than $1000 \mathrm{~m}$ from the parking place, \\
\hline & 0.5 - less than $1000 \mathrm{~m}$ from the parking place, \\
\hline & 1 - more than $1000 \mathrm{~m}$ from the stop of public transport \\
\hline
\end{tabular}




\begin{tabular}{|c|c|}
\hline \multirow{3}{*}{$\begin{array}{l}\text { presence of tourist } \\
\text { infrastructure }\end{array}$} & 0 - more than $10 \mathrm{~km}$ from the site existing tourist facilities, \\
\hline & $0.5-5-10 \mathrm{~km}$ tourist facilities, \\
\hline & 1 - less than $5 \mathrm{~km}$ tourist facilities \\
\hline \multirow[t]{3}{*}{ local products } & 0 - no local products related to a site, \\
\hline & 0.5 - some products, \\
\hline & 1 - emblematic site for some local products \\
\hline \multicolumn{2}{|l|}{ Conservation values } \\
\hline \multirow[t]{3}{*}{ actual threats and risks } & 0 - high both natural and atrophic risks, \\
\hline & 0.5 - existing risks that can disturb the site, \\
\hline & 1 - low risks and almost no threats \\
\hline \multirow[t]{3}{*}{ potential threats and risks } & 0 - high both natural and athrophic risks, \\
\hline & 0.5 - existing risks that can disturb the site, \\
\hline & 1 - low risks and almost no threats \\
\hline \multirow[t]{3}{*}{ current status of a site } & 0 - continuing destruction of the site, \\
\hline & $\begin{array}{l}0.5 \text { - the site destroyed, but now with management measures } \\
\text { for avoid the destruction, }\end{array}$ \\
\hline & 1 - no destruction \\
\hline \multirow[t]{3}{*}{ legislative protection } & 0 - no legislative protection, \\
\hline & 0.5 - existing proposal for legislative protection, \\
\hline & $\begin{array}{l}1 \text { - existing legislative protection (Natural monument, Natural } \\
\text { reservation...) }\end{array}$ \\
\hline \multicolumn{2}{|l|}{ Added values } \\
\hline \multirow{3}{*}{$\begin{array}{l}\text { cultural values: presence of } \\
\text { historical/archaeological/ } \\
\text { religious aspects related to } \\
\text { the site }\end{array}$} & 0 - no cultural features, \\
\hline & $\begin{array}{l}0.5 \text { - existing cultural features but without strong relation to } \\
\text { abiotic features, }\end{array}$ \\
\hline & $\begin{array}{l}1 \text { - existing cultural features with the strong relations to } \\
\text { abiotic features }\end{array}$ \\
\hline \multirow[t]{3}{*}{ ecological values } & 0 - not important, \\
\hline & 0.5 - existing influence but not so important, \\
\hline & $\begin{array}{l}1 \text { - important influence of the geomorphologic feature on the } \\
\text { ecologic feature }\end{array}$ \\
\hline
\end{tabular}




\begin{tabular}{|l|l|}
\hline $\begin{array}{l}\text { aesthetic values: number } \\
\text { of colours; structure of the } \\
\text { space, viewpoints }\end{array}$ & 0 - one color, \\
\cline { 2 - 2 } & 0.25 - 2-3 colors, \\
\cline { 2 - 2 } & 0.5 - more than 3 colors; \\
\hline & 0 - only one pattern, \\
\hline & 0.25 - two or three patterns clearly distinguishable, \\
\hline & 0.5 - more than 3 patterns; \\
\hline $0-$ none, \\
\hline $0.25-1-2$, \\
\hline $0.5-3$ and more
\end{tabular}

Source: author (2013)

\section{Conclusions}

Geodiversity is probably the most important resource for the geotourism activities. It is evident that all the geodiversity cannot be used for geotourism; tourist use of geodiversity is generally made through the exploitation of geoheritage (represented here by the geosites and geomorphosites). For the detection of such sites, it is necessary to do the inventory and evaluation of potential sites - this can be achieved by using the concept of "geomorphosites". This concept includes inventorying and identification of suitable sites and plenty of assessment methods for the evaluation of the geosites and geomorphosites from different points of view. It is evident that all the methods cannot be used for the geotourism purposes - some of them are not equilibrated and they are focused unilaterally, so they do not meet the principles and key features of geotourism. These methods were assessed by using the proposed criteria based on the definitions and principles of geotourism. It was found that the most suitable method for assessing the geosites and geomorphosites for the geotourism purposes were the methods introduced by Pralong (2005), and Pereira, et al. (2007).

Based on this analysis, the modified method for the geosite and geomorphosite assessment for the geotourism purposes was proposed. The assessment criteria came out from the principles and key features of geotourism and from the method used by Pralong (2005), and Pereira, et al. (2007). The criteria are divided into five groups and they are intended to cover all the key features of geotourism. The first group (scientific and intrinsic values) is based on the principles "geologically based" and "integrity of place" and geology and geomorphology - oriented definitions of geotourism. The second group of criteria (educational values) comes out from the fact that most of the definitions of geotourism emphasize the educational issues; this group is based on the principles " "environmentally educative", "protection and enhancement of destination appeal ", "interactive interpretation and evaluation”. The third group of criteria (economic values) considers 
the principles "tourist satisfaction", "tourist satisfaction", "locally beneficial", "market selectivity and diversity", "community involvement and benefit". The fourth group (conservation value) is based on the principles "sustainable", "land use and planning" and "conservation of resources" and partly on the geoconservation principles. The last group of the criteria (added values) comes out of the fact that geotourism does not consider only the natural aspects, but also cultural and aesthetic aspects of the site.

Although the proposed method is numerical which should reduce the subjectivity, there is always a degree of subjectivity due to the fact that the real value of some criteria cannot be measured and it depends, for example, on assessor's experience, knowledge and preferences.

To validate this method and its criteria, it is necessary to test it in various areas - it can be applied both in protected areas and other types of areas, independent of their size. Another possibility how to validate the method is to apply the method by a group of independent experts.

Nevertheless, the procedure needs to be improved, refined and more thoroughly validated as the list of assessment criteria is not complete and it is a subject to further discussions.

\section{Acknowledgements}

This article was supported by the project Copernic, reg. No. CZ.1.07/2.4.00/31.0059, which is co-financed by the European Social Fund and the state budget of the Czech Republic.

\section{References}

Andrasanu, A. (2009). Geoeducation - a key part of Geoconservation. Abstract. Studia Universitatis Babes-Bolyai. Geologia, Special Issue, MAEGS - 16, pp. 5. Retrieved from http://bioge.ubbcluj. ro/maegs 16/volume/1\%20secondary\%20school\%20nou.pdf.

Australian Heritage Commission. (1996). Australian Natural Heritage Charter: Standards and principles for the conservation of the places of natural heritage significance. Sydney: Australian Heritage Commission and Australian Committee for the International Union for the Conservation of Nature (IUCN). Retrieved from http://www.defence.gov.au/environment/heritagechart.pdf

Australian Heritage Commission. (2002). Australian Natural Heritage Charter: Standards and principles for the conservation of the places of natural heritage significance. 2nd edition. Canberra: Australian Heritage Commission and Australian Committee for the International Union for the Conservation of Nature (IUCN). Retrieved from http://www.environment.gov.au/system/files/resources/56de3d0a-7301-47e2-8c7c-9e064627alae/files/australian-natural-heritage-charter.pdf.

Barba, F. J., Remondo, J., \& Rivas, V. (1997). Propuesta para un procedimiento para armonizar la valoración de elementos del patrimonio geológico. Zubia, 15, 11-20. Retrieved from http:// dialnet.unirioja.es/servlet/articulo?codigo=110356.

Brilha, J. (2005). Patrimonio Geologico e Geoconservacao: a Conservacao da Natureza na sua Vertente Geológica. Braga: Palimage Editores. 
Bruschi, V. M. (2007). Desarrollo de una metodología para la caracterización, evaluación y gestión de los recursos de la geodiversidad (Doctoral dissertation). Santander: Universidad de Cantabria.

Bruschi, V. M., \& Cendrero, A. (2005). Geosite Evaluation; Can we measure intangible values? Il Quaternario, 18(1), 293-306.

Burek, C. V., \& Prosser, C. D. (Eds.). (2008). The History of Geoconservation: an introduction. London: Geological Society, 1-5. DOI: 10.1144/SP300.1.

Cleal, C. J. (2007). Geoconservation - what on Earth are we doing? In Hlad, B., \& Herlec, U. (Eds.), Regional Conference on Geoconservation: Geological heritage in the South-European Europe. Book of abstracts (p. 25). Ljubljana: Environmnetal Agency of the Republic of Slovenia. Retrieved from http://arsis.net/circular/ProGEO-Abstract.pdf.

Comanescu, L., \& Dobre, R. (2009). Inventorying evaluating and tourism valuating the geomorphosites from the central sector of the Cealhau National park. GeoJournal of Tourism and Geosites, $1(3), 86-96$.

Comanescu, L., et al. (2009). Inventorying and evaluation of geomorphosites in the Bucegi Mountains. Forum Geografic. Studii şi cercetări de geografie si protecția mediului, $8(8), 38-43$.

Coratza, P., \& Giusti, C. (2005). Methodological proposal for the assessment of the scientific quality of geomorphosites. Il Quaternario, 18(1), 305-313.

Dingwall, P., Weighell, T., \& Badman, T. (2005). Geological world heritage: a global framework. A Contribution to the Global Theme Study of World Heritage Natural Sites. IUCN, WCPA, UNESCO.

Dixon, G. (1996). Geoconservation: An International Review and Strategy for Tasmania. Occasional Paper 35. Hobart, Tasmania: Parks \& Wildlife Service.

Dowling, R. K. (2011). Geotourism's Global Growth. Geoheritage, 3(1), 1-13. DOI: 10.1007/s12371010-0024-7.

Dowling, R. K., \& Newsome, D. (Eds.). (2006). Geotourism. Oxford: Elsevier Ltd.

Eberhard, R. (Ed.). (1997). Pattern and Process: Towards a Regional Approach to National Estate Assessment of Geodiversity. Technical Series No. 2. Canberra: Australian Heritage Commission and Environment Forest Taskforce, Environment Australia.

Erhartič, B. (2010). Geomorphosite assessment. Acta geographica Slovenica, 50(2), 295-319. DOI: 10.3986/AGS50206.

Giusti, C. (2010). From geosites to geomorphosites. Géomorphologie: relief, processus, environnement, 5(2), 123-130.

Grandgirard, V. (1997). Geomorphologie et gestion du patrimoine naturel. La memoire de la Terre est notre memoire. Geographica Helvetica, 52(2), 47-56. DOI: 10.5194/gh-52-47-1997.

Grandgirard, V. (1999). L'évaluation des géotopes. Geologia Insubrica, 4, 59-66.

Gray, M. (2004). Geodiversity: Valuing and Conserving Abiotic Nature. Chichester: John Wiley.

Grube, A., \& Wiedenbein, F.W. (1992). Geotopschutz, eine wichtige Aufgabe der Geowissenschaften. Die Geowissenschaften, 8, 215-219.

Hose, T. A. (1995). Selling the Story of Britain's Stone. Environmental Interpretation, 10(2), 16-17.

Hose, T. A. (2000). European Geotourism - Geological Interpretation and Geoconservation Promotion for Tourists. In Barretino, D., Wimbledon, W. A. P., \& Gallego, E. (Eds.), Geological heritage: its conservation and management (pp. 127-146). Madrid: Sociedad Geologica deEspana/ Instituto Technologico GeoMinero de Espana/ProGEO.

Hose, T. A. (2008). Towards a history of geotourism: definitions, antecedents and the future. In Burek, C. V., \& Prosser, C. D. (Eds.), The History of Geoconservation: an introduction. London: Geological Society. 
Hose, T. A. (2012). 3G's for Modern Geotourism. Geoheritage, 4 (1-2), 7-24.

Ilies, D. C., \& Josan, N. (2007). Preliminary contribution to the investigation of the geosites from Apuseni Mountains (Romania). Revista de geomorfologie, 9, 53-59.

Ilies, D. C., et al. (2009). Estimation of the geomorphostructures with geomorphosite valence in the northern part of the Hunedoara County (Western Romania). Analele Universitătii din Oradea, Seria Geografie, XIX, 41-46.

Joyce, E. B. (2006). Geomorphological sites and the new Geotourism in Australia. Retrieved from http://earthsci.unimelb.edu.au/Joyce/heritage/geotourisminaustralia.html.

Kubalíková, L. (2011). Hodnoceni geomorfologických lokalit v kontextu ochrany neživé přírody: prípadová studie ze západni části národniho parku Podyji a z okoli Maršovského žlebu (Doctoral dissertation). Brno: Masaryk University.

National Geographic Society. (2005). Geotourism Charter. Retrieved from http://travel.nationalgeographic.com/travel/sustainable/pdf/geotourism_charter_template.pdf.

Newsome, D., \& Dowling, R. K. (Eds.). (2010). Geotourism: The tourism of Geology and Landscape. Oxford: Goodfellow Publishers Ltd.

Panizza, M. (1996). Environmental Geomorphology. Amsterdam: Elsevier Ltd.

Panizza, M. (2001). Geomorphosites: concepts, methods and example of geomorphological survey. Chinese Science Bulletin, 46 - Suppl., 4-6. DOI: 10.1007/BF03187227.

Panizza, M. (2009). The Geomorphodiversity of the Dolomites (Italy): A Key of Geoheritage Assessment. Geoheritage, 1(1), 33-42.

Panizza, M., \& Piacente, S. (1993). Geomorphological assets evaluation. Zeitschrift fur geomorfologie, Supp. Band 87, 13-18.

Panizza, M., \& Piacente, S. (2005). Geomorphosites: a bridge betwenn scientific research, cultural integration and artistic suggestion. Il Quaternario, 18 (1), 3-10.

Panizza, M., \& Piacente, S. (2008). Geomorphosites and geotourism. Revista Geográfica Acadêmica, 2(1), 5-9.

Pereira, P. (2006). Património geomorfológico: conceptualização, avaliação e divulgação. Aplicação ao Parque Natural de Montesinho (Doctoral dissertation). Braga: Universidade do Minho.

Pereira, P., \& Pereira, D. (2010). Methodological guidelines for geomorphosite assessment. Géomorphologie: relief, processus, environnement, 1(3), 215-222.

Pereira, P., et al. (2007). Geomorphosite assessment in Montesinho Natural Park (Portugal). Geographica Helvetica, 62(3), 159-168.

Piacente, S. (2005). Geosites and geodiversity for a cultural approach to geology. Il Quaternario, 18 (1), 11-14.

Pralong, J. P. (2003). Valorisation et vulgarisation des sciences de la Terre : les concepts de temps et d'espace. In Reynard, E., Holzmann, C., Guex, D., \& Summermatter, N. (Eds.), Géomorphologie et tourisme, Actes de la Réunion annuelle de la Société Suisse de Géomorphologie (SSGm), Finhaut, 21-23 septembre 2001, Travaux et Recherches $n^{\circ} 24$ (pp. 115-127). Lausanne: Institut de Géographie.

Pralong, J. P. (2005). A method for assessing tourist potential and use of geomorphological sites. Géomorphologie: relief, processus, environnement, 1(3), 189-196.

Pralong, J. P., \& Reynard, E. (2005). A proposal for a classification of geomorphological sites depending on their tourist value. Il Quaternario, 18(1), 315-321.

ProGEO. (2011). Conserving our shared geoheritage - a protocol on geoconservation principles, sustainable site use, management, fieldwork, fossil and mineral collecting. Uppsala: ProGEO. Retrieved from http://www.progeo.se/progeo-protocol-definitions-20110915.pdf. 
Prosser, C., Murphy, M., \& Larwood, J. (2011). Geological Conservation: a guide to good practice. Riverside Exchange, UK: English Nature.

Reynard, E. (2004). Geosite. In Goudie, A. S. (Ed.), Encyclopedia of geomorphology. London: Routledge.

Reynard, E. (2005). Géomorphosites et paysages. Géomorphologie: relief, processus, environnement, $1(3), 181-188$.

Reynard, E. (2008). Scientific research and tourist promotion of geomorphological heritage. Geogr. Fis. Dinam. Quat., 31, 225-230.

Reynard, E., Coratza, P., \& Regolini-Bissig, G. (Eds.). (2009). Geomorphosites. Mnichov: Verlag.

Reynard, E., et al. (2003). Géomorphologie et tourisme: quelles relations? In Reynard, E., Holzmann, C., Guex, D., \& Summermatter, N. (Eds.), Géomorphologie et tourisme, Actes de la Réunion annuelle de la Société Suisse de Géomorphologie (SSGm), Travaux et Recherches $n^{\circ} 24$, Finhaut, 21-23 septembre 2001 (pp. 1-10). Lausanne: Institut de Géographie.

Reynard, E., et al. (2007). A method for assessing the scientific and additional values of geomorphosites. Geographica Helvetica, 62(3), 148-158. DOI: 10.5194/gh-62-148-2007.

Reynolds, J. (2001). Notes to accompany RIGS recording, assessment and designation and notification sheets. In Notes on the UKRIGS Conference 2001. Penirth: UKRIGS Conference. Retrieved from http:// wiki.geoconservationuk.org.uk/images/8/8d/Assessinfo.pdf.

Serrano Cañadas, E., \& Gonzáles-Trueba, J. J. (2005). Assessment of geomorphosites in natural protected areas: the Picos de Europa National Park (Spain). Géomorphologie: relief, processus, environnement, 1(3), 197-208 .

Sharples, C. (1993). A Methodology for the Identification of Significant Landforms and Geological Sites for Geoconservation Purposes. Hobart, Tasmania: Forestry Commission Tasmania.

Sharples, C. (1995). Geoconservation in forest management - principles and procedures. Tasforests, 7(12), 37-50.

Sharples, C. (2002). Concepts and principles of geoconservation. Hobart, Tasmania: Parks \& Wildlife Service. Retrieved from http://xbiblio.ecologia.edu.mx/biblioteca/Cursos/Manejo/Geoconservation.pdf.

Slomka, T., \& Kicinska-Swiderska, A. (2004). Geotourism - the basic concepts. Geoturystyka, 1, 2-5.

Stueve, A. M., et al. (2002). The Geotourism Study: Phase 1 Executive Summary. National Geographic Traveller, Travel Industry Association of America. Retrieved from http://destinationcenter.org/wp-content/uploads/2012/01/geotourism1-survey.pdf

UNESCO. (1972). Convention concerning the protection of the world cultural and natural heritage. Retrieved from http://whc.unesco.org/archive/convention-en.pdf

Vitaliano, C. J. (2007). Geomythology. In Piccardi, L., \& Masse, W. B. (Eds.), Myth and Geology. London: Geological Society.

Vujicic, D., et al. (2011). Preliminary geosite assessment. Acta geographica Slovenica, 51(2), 361377.

Zouros, N. (2005). Assessment, protection, and promotion of geomorphological and geological sites in the Aegean area, Greece. Géomorphologie: felief, processus, enivronnement, 1(3), 227-234. DOI: $10.4000 /$ geomorphologie.398.

Zouros, N. (2007). Geomorphosite assessment and management in protected areas of Greece. Case study of the Lesvos Island - coastal geomorphosites. Geographica Helvetica, 62(3), 169-180. DOI: $10.5194 /$ gh-62-169-2007. 